\title{
Nordestinidade: identidade e machismo no forró pé de serra e no forró eletrônico
}

\author{
Micheliny Verunschk
}

TROTTA, Felipe.

No Ceará não tem disso não:

nordestinidade e macheza no forró

contemporâneo. Rio de Janeiro, Folio

Digital Letra e Imagem, 168 p., 2014.

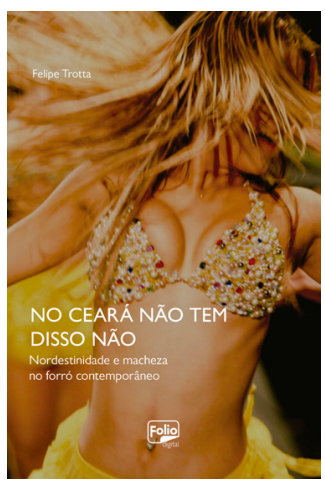

Resumo: Em No Ceará não tem disso não: nordestinidade e macheza no forró contemporâneo, Felipe Trotta analisa a construção da identidade nordestina e o manejo dos estereótipos genéricos nos discursos do forró tradicional e do forró eletrônico na construção.

Palavras-chave: identidade; nordestinidade; machismo; forró.

Abstract: Northeasterness: identity and male chauvinism in forró pé de serra and in electronic forró. In No Ceará não tem disso não: nordestinidade e macheza no forró contemporâneo, Felipe Trotta analyses the discourse of traditional forró music and electronic forró music, and the demands for the maintenance/rebuilding of northeastern identity in narratives permeated by male chauvinism, stereotypes and binary oppositions.

Keywords: identity; northeasterness; male chauvinism; forró music. 
Os discursos de identidade não raro se apropriam de termos como raízes, tradição, história, cultura, povo. Na criação de um sentimento de pertencimento pretensamente universal, esses discursos inventam ou ressignificam valores, imagens, representações culturais. Eric Hobsbawm, em ensaio sobre a questão da identidade, alerta: "as nações são entidades historicamente novas fingindo terem existido durante muito tempo" (HOBSBAWM, 1998, p. 285). Não seria, pois, exagero afirmar que todo discurso de identidade se fundamenta numa ficção ou que toda tradição tem um pé na invenção. É sob essa perspectiva que Albuquerque Júnior analisa o recorte político, geográfico e cultural nomeado como "Nordeste", região brasileira que surge como uma criação recente, de meados do século XX, sendo composta como um artesanato de confrontos, cuja feitura envolveu tanto a política como obras literárias, sociológicas, das artes visuais, e de vários produtos oriundos da cultura de massas, entre estes, a música (ALBUQUERQUE JúNIOR, 2001).

Na composição desse cenário, a música, de fato, ocupa um papel privilegiado, sobretudo pela influência de Luiz Gonzaga, o "rei do baião", responsável por instituir e difundir, especialmente a partir da era do rádio, a imagem de um Nordeste idílico e harmônico, um espaço de saudades e esperanças. A música imprimirá, de modo mais eficaz que qualquer outro veículo, uma personalidade e um léxico à "cultura nordestina", num processo de estabelecimento e consolidação de uma identidade regional hegemônica. Paradoxalmente, esta música, difundida nas ondas do rádio e que veicula conteúdos arraigados a valores tradicionais e rurais, estruturalmente se comporá de elementos fincados numa sonoridade moderna que opera a partir de um mix de linguagens musicais e culturais muito bem calculadas.

Em No Ceará não tem disso não: Nordestinidade e macheza no forró contemporâneo, Felipe Trotta, analisa os atuais sentidos tanto dos sentimentos de pertencimento quanto da estereotipia identitária nordestina. É nos confrontos entre o "forró pé de serra" e o "forró eletrônico" que o autor localiza o debate sobre as dinâmicas da "nordestinidade" em seus aspectos estéticos e morais. Para Trotta, o forró é o eixo central através do qual se reatualizam os principais referenciais da identidade nordestina e é nas ambiguidades e confluências que marcam os dois estilos de forró que tradições são continuamente reinventadas. O forró pé de serra, a despeito de ter sua origem localizada em determinações culturais e mercadológicas não muito distantes do universo do forró eletrônico, se afirma como herdeiro das tradições culturais, legitimando-se num discurso de continuidade que tem justamente na figura de Luiz Gonzaga o seu mentor. O forró eletrônico, distanciado dessa matriz, acusada de ser representante direta da dispersão e diluição culturais, é refutado por discurso inflamado balizado por um sentimento passional e preservacionista.

Forró pé de serra e forró eletrônico duelam, assim, em espaços marcados pelo binarismo: o novo contra o antigo, o jovem contra o velho, o rural contra o urbano. O forró eletrônico é reiteradamente responsabilizado por uma quebra de princípios e de respeito, por uma traição para com os valores hereditários transmitidos pela sanfona. 
Imputa-se a ele um decaimento na qualidade musical, manifestado pelo afastamento de uma certa autenticidade representada pelos forrozeiros tradicionais, mais ou menos afastados do apelo midiático e das demandas da sociedade de consumo. $\mathrm{O}$ autor relativiza essas oposições e aproxima as duas vertentes por meio de categorias subordinadas ao código moral masculino, marcadamente machista, categorias estas que se entrelaçam. É no ambiente da festa, nos limites do corpo, do humor e do duplo sentido que se estabelecem narrativas que aproximam tendências que só aparentemente são inconciliáveis. Se os projetos estéticos as distanciam, por um lado, por outro, compartilham o mesmo discurso moral.

No universo simbólico da festa nordestina desenhada nas letras das músicas, tudo é erotismo e performance. Safadeza, sutileza e mesmo a abordagem direta de temas crus são estratégias recorrentes na construção de um imaginário masculino em torno daquele fato cultural. O forró é determinado como o espaço do "cabra macho", conquistador hiperssexualizado, que não foge às brigas e que afoga as mágoas no álcool. O protagonismo feminino não ocupa quantitativamente espaço tão relevante. O autor estabelece, contudo, uma notável distinção no que diz respeito às tensões de gênero. Se no forró tradicional o papel da mulher sofre um apagamento e a conduta masculina é pautada pela conquista sexual, pela reiteração contínua de uma "macheza" performatizada e pelo estabelecimento de papéis socialmente aceitos para o homem e para a mulher, por outro lado, no forró eletrônico a presença feminina se esboça um tanto mais atuante.

As personagens femininas do forró pé de serra desfilam sob o domínio irrestrito do macho. Para usar alguns dos exemplos oferecidos por Trotta: Rosinha, personagem de várias músicas de Gonzaga, é a mulher idealizada, inerte, cujo papel nas composições pouco ultrapassa a função decorativa. Sabe-se dos seus olhos verdes, de que ficou para trás esperando o retorno do homem amado num sertão castigado pela seca, sabe-se mesmo que é uma "mulher séria". Entretanto, Rosinha não ultrapassa os limites estabelecidos pela narrativa masculina. Na música Ana Maria, de Santanna, a mulher continua sem autonomia: eu beijei Ana Maria/por causa disso quase entro numa fria/Ana Maria tinha dono e eu não sabia. Ao possuir um dono, Ana Maria é despersonalizada, coisificada. Na música Se você quiser é assim, da banda Calcinha Preta, ao contrário, a mulher se nega a continuar num relacionamento abusivo: quem disse que eu preciso de um amor assim/ que pega no meu pé, que quer mandar em mim. Não se trata ainda de uma total mudança de paradigmas, posto que o discurso masculino reitera as posições do patriarcado, no entanto, percebe-se a construção de um novo espaço para o debate dessas tensões.

É desse modo que lugares de conflito e trocas entre os atores responsáveis pela construção ou remodelação da identidade nordestina se emaranham nas questões relativas às negociações e continuidades envolvendo forró, ritmo e retrato do sujeito nordestino. Os embates entre o antigo e o moderno surgem menos maniqueístas ao desvelarem um diálogo que, à primeira vista, parece improvável mas que, em sua matriz, se mostra fértil e incessante. As coincidências e choques entre as duas vertentes de forró desarmam o olhar que se volta para a dinâmica da sociedade nordestina, captando uma trama rizomática e deslizante. 
Micheliny Verunschk é doutoranda em Comunicação e Semiótica pela PUC-SP (bolsista Capes) e mestre em Literatura e Crítica Literária, também pela PUC-SP.

verunschk@gmail.com

\section{Referências}

ALBUQUERQUE Júnior, Durval Muniz de. A invenção do Nordeste e outras artes. Recife: FJN, Editora Massangana; São Paulo: Cortez, 2001.

HOBSBAWM, Eric. Sobre História. Tradução por Cid Knipel Moreira. São Paulo: Companhia Das Letras, 1998. 